\title{
Exploring the Dialogue Process on Kashmir Issue : an Interplay among Religious, Political and Economic Phenomena
}

\author{
Muhammad Khan (Ph.D) \\ Assistant Professor \\ Jazan University \\ Jazan, Saudi Arabia
}

\begin{abstract}
There are ever new emerging ideas about globalization of the world especially certain debates longing for peace worldwide. The human historyshows that the best solution to different issues is dialogue and not resisting to disputes. The world has become a global village and it needs to develop and maintain a sustainable peace for the betterment of humanity. The present study explored the continualprocess of interfaith and intercultural dialogue between India and Pakistan towards the subcontinent and ultimately global peace, focusing specifically on religious, economic, political and social aspects in Kashmir issue. Apparently Kashmir is a religious conflict but the ground realities are self-evident that the obstacles are: strategic, political and economic issues and not only religion.A meticulous analysis of the data helped concluding the reconciliation process as a ball moving to and fro without scoring even a single goal ensuring regional peace.India and Pakistan have to change their intentions in the light of Kashmiris' intentions, their political right, self-rule for the sake of democracy and its promotion in the region. Only India or Pakistan or Kashmiris or UN, individually and in isolation cannot solve Kashmir issue instead all parties need to be equal participants in a meaningful dialogue performing their due roles.The dire need is to save the people of Kashmir on humanitarian grounds.
\end{abstract}

Keywords:dialogue, cultural, ethnic, political, strategic, economic, peace, regional \& global.

\section{Introduction}

The present study interrogated the process of dialogueon Kashmir issue between India and Pakistan,specifically focusing on the interplay among religious, political and economic phenomena. A successful dialogue may guaranteesustainable peace in the Subcontinent and South Asia. The Kashmir conflict is a territorial conflict primarily between India and Pakistan, having started just after the partition of India in 1947.Kashmir issue is an alarming nuclear flashpoint between India and Pakistan which can explode anytime if the issue left unresolved."For over fifty years, India and Pakistan, have fought over Jammu and Kashmir both on the battlefield and at the negotiating table; both countries want to absorb it within their borders, neither of them has succeeded in doing so entirely" (Schofield, 2003, p. xi). Apparently Kashmir is religious conflict but the ground realities are self-evident that the obstacles are: strategic, political and economic issues and not only religion. A meticulous analysis of the data helped concluding the reconciliation process as a ball moving to and fro without scoring even a single goal ensuring regional peace. "The continuing presence of militant activity, used both by Pakistan and India to lend weight to their respective propaganda" (Schofield, 2003, p.201). India and Pakistan have to change their intentions in the light of Kashmiris' intentions, their political right, self-rule for the sake of democracy and its promotion in the region. Only India or Pakistan or Kashmiris or UN, individually and in isolation cannot solve Kashmir issue instead all parties need to be equal participants in a meaningful dialogue performing their due roles. The call of the time is to save the helpless people of Kashmir and not destroy and eliminate them. There is military occupation in Kashmir. The ideas of secular state and democracy are empty slogans and have nothing to do with Kashmiris' sufferings and their everyday life problems. Both India and Pakistan are in a state of what to do and ever failed to resolve the Kashmir issuefor one or the other reason.Apparently, they want only the land of Kashmir and not innocent people of Kashmir. All this is the result of some immature historical decisions. 


\section{Theoretical Framework}

An unquestionable reality is that worldwide interfaith, political and economic crises need a meaningful dialogue for better understanding of ground realities.Dialogue is the only solution for peace among nations and religions. Hans Kung's important quote, "No peace among the nationswithout peace among the religions, no peace among the religionswithout dialogue between the religions and no dialogue between the religionswithout investigation of the foundation of the religions"("Kung'sQuotes",2005). It seems necessary to understand as to what is 'interfaith' dialogue. The history of interfaith dialogue is as ancient as religion itself. Interfaith dialogue generally includes major religions of the world Islam, Christianity and Judaism, whereas 'inter-ethnic' or inter-religious dialogue encompasses different ethnic groups within the same religion. For instance 'Sunni', 'Shiah', in Islam and certain 'denominations' in Christianity, are some of the examples of inter-ethnic groups.An intensive study reveals that basic message of the main religions is quite common.The yawning gap of so called differences, confusion and misunderstanding can be bridged through some useful, meaningful and effective dialogue.

Islam is based on the principle of preaching which is another name for peaceful negotiation. Violence is totally forbidden in Islam. There is only one exception to this ban and that is when it is engaged in self-defense. This can take place only at the time of external invasion, and such action is the prerogative of an established government ("Dialogue in Islam", 2018). The Prophet of Islam started his mission in 610 A.D. This mission was to communicate his ideology to people by talking to them, listening to their objections and trying to convince them of his viewpoint by means of arguments. One of the initial Qurānic verses revealed to him was that the ideology given by Allah (SWT) to the Prophet Muhammad (MPBUH) should be spread by him among the people, "And proclaim the Grace of your Lord" (93:11). The Prophet's ideology was based on monotheism, whereas his Arab contemporaries believed in polytheism. The Quran lays down certain meaningful guidelines to make the dialogue fruitful,: "Invite to the way of your Lord with wisdom and fair preaching, and argue with them in a way that is better. Truly, your Lord knows best who has gone astray from His path, and He is the Best knower of those who are guided" (16:125).The Quran makes this quite explicit:"Good deed and the evil deed cannot be equal. Repel the evil with one which is better, then verily, he between whom and you there was enmity (will become) as though he was a close friend" (41:34). The Quran further says, "Say: (O Muhammad) "O People of the Scriptures (Jews and Christians)! Come to a word that is just between us and you, that we worship none but Allah (alone) . . ." (3:64). Preferably, a dialogue should be opened un-controversially on some common ground."The sequence of the discussion, therefore, should be from agreement to difference of opinion and then back to agreement" . . .("Dialogue in Islam", 2018). A dialogue, with good intentions on both sides, should go for reconciliation with justice and not purely a game of totally lose or win.

In Islam, the formula for social peace, social harmony and inter-faith dialogue is based on peaceful co-existence as has been given in the following verse of the Quran:"To you be your religion and to me my religion (Islamic Monotheism)" (109:6). It means that in case of some disagreement, both parties should take their own ways without any oppression and suppression. In fact:

"It is hatred, which has to be eliminated, and not difference of opinion. People may have their differences in belief, religion, culture, etc., but while following their religion, they have to have mutual respect for others and discover a common bond between them, which shows them all to be human beings.That is how; the practice of dialogue in terms of bilateral negotiation enjoys the position of an established principle in Islam" ("Dialogue in Islam”, 2018).

Human history recorded a continuous chain of religious, political and economic dialogue. Dialogue wherever and whatever it is, "refers to cooperative, constructive and positive interaction between people of different religious traditions . . . at both the individual and institutional levels" ("Interfaith Dialogue", 2017). On the contrary,in the present modern world people talk a lot and write abundantly about worldwide dialogue on certain issues but ultimately proves meaningless for one or the other reason."From the Qur'anic reports, Islam has concluded that there are two ways to intellectual debate or struggle. . . There is (i) 'callous or violent style', (ii) the other way of intellectual debate is that of "non-violent or peaceful way" (Hussain, 2003, p.65). This means that violent style must not be practiced because it adopts the notion of attacking the opponents leaving nothing in degrading and hurting their feelings. However, 'non-violent style or peaceful way of dialogue' is appreciated which goes on and on to settlethe disputes, crises and differences whatever through mutual respect, leniency and love for others. At the same time participants of a dialogue from both sides should be optimistic and not pessimistic. 
The Qur'an says, "And when a community among them said: "Why do you preach to people whom Allah is about to destroy or to punish with a severe torment?" (The preachers) said: "In order to be free from guilt before your Lord (Allah), and perhaps they may fear Allah" (7:164).Unfortunately the present day dialogue is just a sit-stand show."Interfaith dialogue and action have taken place for many centuries.

The emperor Akbar the great, for example encouraged tolerance in Mughal India, a diverse nation with people of various faith backgrounds, including Islam, Hinduism, Sikhhism and Christianity" ("Interfaith Dialogue", 2018). Unfortunately, the political self-centeredness has spoiled the very objectives of dialogue among different communities.

The process of dialogue includes: Parliament of the world religions (1893), dialogue between Abrahamic faiths Judaism, Christianity, Islam, Interfaith Movement (1960), Roman Catholic Church's policy towards non-Christian religions (1965), A common Word between Us (Muslims) and You (non-Muslims) (2007) and a historic "Interfaith Dialogue Conference" (2008) was initiated by King Abdullah of Saudi Arabia and held in Madrid (Spain) hosted by King Juan Carlos ("Interfaith Dialogue", 2018) Despite these efforts the world of dialogue could not reap the least expected fruits and all this is an open and alarming question to our partial intentions and sincerity. The very aim of the dialogue should be the establishment of welfare societies in the world. The same has been going on in Kashmir dialogue for the last seven decades wherein politicians are serving their own materialistic interests and attachments; altogether ignoring fundamental and political rights of Kashmiri people. Presently, Kashmir seemsnot only a religious issue but also experiencing strategic, political and economic crises.

\section{An Overview of Kashmir Issue}

After centuries of Hindu and Buddhist rule, Muslim Moghul emperors took control of Kashmir in the 15th century, converted the population to Islam and incorporated it into the Moghul Empire. Islamic Moghul rule should not be confused with modern forms of authoritarian Islamic regimes. The Moghul empire, characterized by the likes of Akbar the Great (1542-1605) embodied Enlightenment ideals of tolerance and pluralism a century before the rise of the European Enlightenment. Moghuls left their mark on the subsequent Sufi-inspired form of Islam that dominated the subcontinent in India and Pakistan.Historically, Kashmir referred to the Kashmir Valley. Today, it denotes a larger area that includes -(i) the Indian-administered state of Jammu and Kashmir which consists of Jammu, the Kashmir Valley, and Ladakh, (ii) the Pakistan-administered territories of Azad Kashmir and Gilgit-Baltistan and (iii) the Chinese-administered regions of Aksai Chin and the Trans-Karakoram Tract.

India, Pakistan and China all claim partial or complete ownership of Kashmir. India-controlled: One state, called Jammu and Kashmir, makes up the southern and eastern portions of the region, totaling about $45 \%$ of Kashmir. Pakistan-controlled: three areas called Azad Kashmir, Gilgit and Baltistan make up the northern and western portions of the region, totaling about 35\% of Kashmir. China-controlled: One area called Aksai Chin in the northeastern part of the region, equaling 20\% of Kashmir.India also alleges Pakistan has ceded 3,220 square miles in Kashmir to China ("Kashmir Conflict", 2017) Pakistan claims Jammu and Kashmir based on its majority Muslim population, whereas China claims the Shaksam Valley and Aksai Chin. 


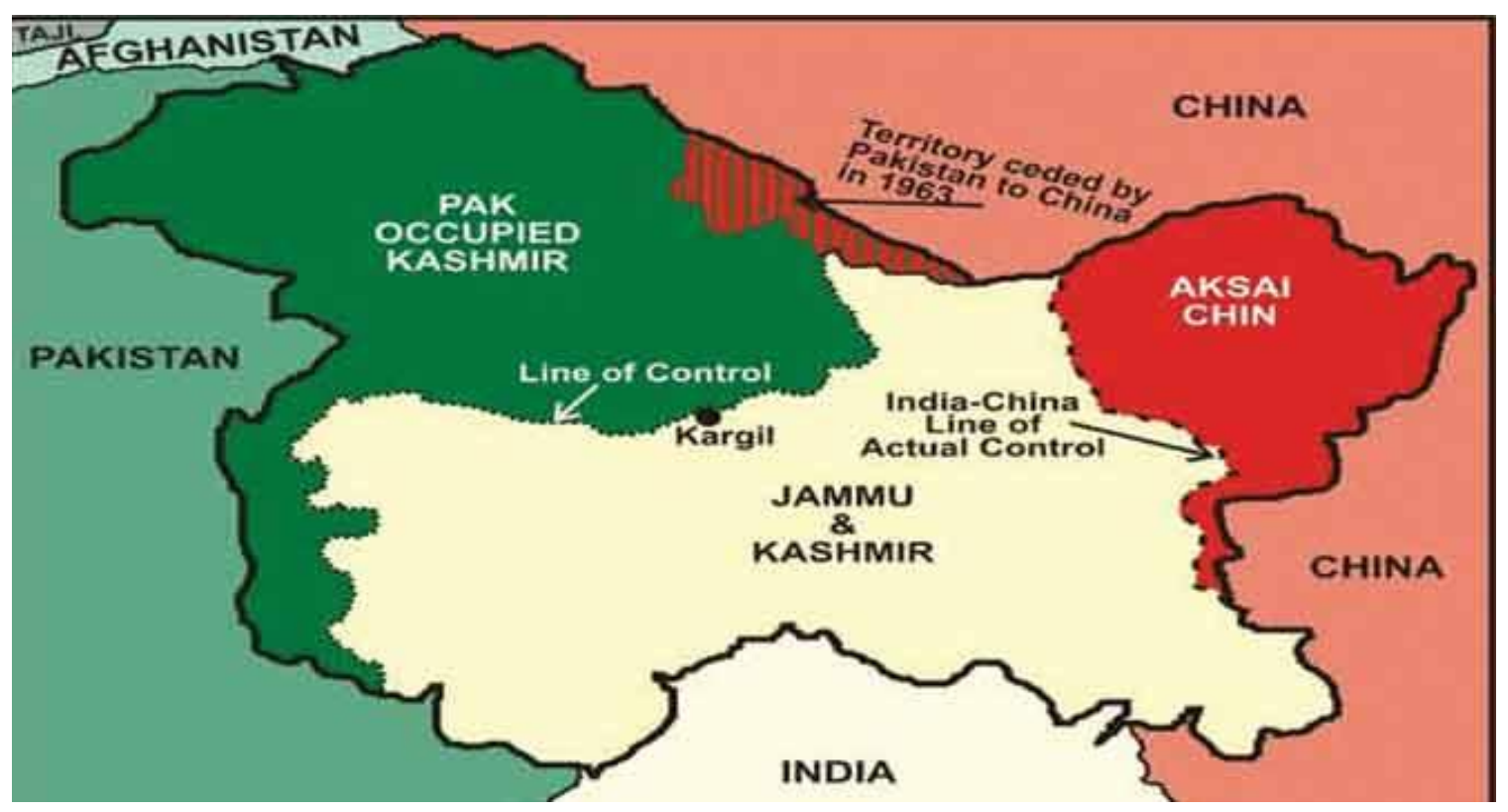

Source: https://www.shutterstock.com

The Kashmir conflict is a territorial conflict primarily between India and Pakistan, having started just after the partition of India in 1947.India and Pakistan were partitioned in 1947. Kashmir was split as well, with two-thirds going to India and one-third going to Pakistan, even though India's share was predominantly Muslim, like Pakistan. Muslims rebelled and India repressed them. War broke out and it wasn't settled until 1949. United Nation intervened forcease-fire and a resolution calling for a referendum, or plebiscite, allowing Kashmiris to decide their future for themselves. India has never implemented the resolution.Instead, India has maintained what amounts to an occupying army in Kashmir, cultivating more resentment from the locals than fertile agricultural products.

Some historical blunders have life-long repercussions.The Treaty of Amritsar, signed on 16 March 1846 is one of them. According to Saifuddin (2018), "The Treaty of Amritsar signed by the British and Maharaja Gulab Singh in 1846 proved to be the final nail in the coffin of Kashmiris' subjugation. It resulted in the 1931 revolt, under the leadership of Sheikh Muhammad Abdullah" (Soz, 2018, p. ix).In a confused state of affairs, Sheikh Abdullah was immediately dismissed on 8th August, 1953, arrested and later jailed for eleven years, accused of conspiracy against the State in the infamous "Kashmir Conspiracy Case". According to Sheikh Abdullah his dismissal and arrest were engineered by the central government headed by Prime Minister Jawaharlal Nehru. Thereafter, "The undemocratic dismissal of the Farooq Abdullah's government on 2nd July,1984 further created a divide and alienated Kashmiris from Indian's heartland" (Soz, 2018, p.x). All this chain of incidents is self-evident that the occupying forces longed for only the land of Kashmir the most beautiful and not for the welfare of Kashmiris on humanitarian grounds. Soz (2018) further says that it is accepted widely in India as well as other parts of the world that Kashmir dispute has to be sorted out through dialogue and discussion with the three main stakeholders - the people of Jammu \&Kashmir, India and Pakistan. However, the truth of the matter is that today because of the constant, unjustifiable postponement of the solution of the conflict, the Kashmir problem has played havoc with the crucial relations between India and Pakistan and it has been irretrievably thrust onto the scene of the world politics (Korbel, 1954, p.303-4).Modern India's founders, Jawaharlal Nehru and Mahatma Gandhi, both had Kashmiri roots which partially explain India's attachment to the region. To India, "Kashmir for the Kashmiris" means nothing. Indian leaders' standard line is that Kashmir is "an integral part" of India.

Not only India and Pakistan but also the whole world needs to realize sensitivity of the Kashmir issue. "Kashmir has turned out to be a great suppression story" (Ali, 2011, p.2). In a word, review of the book, 'Kashmir: The Case for Freedom', says that Kashmir is one of the most protracted and bloody occupations in the world-and one of the most ignored issue. "In 1948 the Indian government made a formal complaint to the Security Council of the United Nations against Pakistan's 'aggression"” (Schofield, 2003, p.xii). This approach made Kashmir as an international issue. Ultimately, UNO passed a resolution of plebiscite to solve the issue that demanded international attention. 
Under an Indian military rule that, at half a million strong, exceeds the total number of US forces in Iraq and Afghanistan, freedom of speech is non-existent, and human- rights abuses and atrocities are routinely visited on its Muslim-majoritypopulation but ignored by its own corrupt politicians. In the last two decades alone, over seventy thousand people have died.The passionate call is to end the unjustifiable occupation, and extend the right of self-determination for the Kashmiri people. "Kashmiris will increasingly speak for themselves. One can only hope that their voices will finally penetrate our indifference and even occasionally prick our conscience" (Ali, 2011, p.6)

Azad Jammu and Kashmir (AJK) President SardarMasood Khan said there was no military solution to the Kashmir issue and India would have to initiate dialogue with Pakistan and Kashmiris to find a way for a peaceful settlement of this longstanding dispute.At the heart of dialogue is inter-religious dialogue, because religion is the most comprehensive of all the human disciplines. Different participants of a dialogue may conquer others' hearts through sincere and impartial dialogue. The people with differences can be united, the way 'the fall of Berlin wall in 1989' brought East and west German closer and all evil designs against each other got an end. "Kashmir is now one of the most dangerous situations in the world" (Schofield, 2003, p.246). It is the high time the UN secretary general should take a step forward and appoint a special representative to explore a viable solution to this festering conflict and ensure lasting peace and stability in the region. "The activity of peace making is honored and encouraged in the (Qur'anic) verses such as al-Afal: 8:61" (Kurucan, 2012, p.39).

But if they incline towards peace, you [O Prophet] must also incline

Towards it (peace), and put your trust in God: He is the All Hearing,

The All Knowing (Qur'an 8:61).

There is no military solution to Kashmir issue.The UN and world powers need to intervene in setting a stage for the settlement of the Kashmir issue before these two nuclear states indulge in a full-fledged war which will be a massive disaster engulfing not only the South Asian region but also a large part of the world. ("No Military Solution", 2018). The world will surely witness in the decades to come, the future is not rigidity of nation states but the fluidity of cross-cultural and regional communication. Ultimately the people will realize that fighting for a piece of land is so tragic and the best option is that the suppressed and oppressed people should be allowed to live freely and peacefully which is their fundamental right and demand of a welfare state.

\section{Research Questions}

The researcher focused on finding answers to the research questions:

(i) Is Kashmir a religious or political issue?

(ii) What do the Kashmiri people want - independence, political rights or accession to India or Pakistan through self-determination?

(iii) What are their economic problems?

(iv) What are religious crises in Kashmir?

(v) What are the intentions of Pakistan and India on Kashmir issue?

(vi) What are the possible solutions to the long outstanding issue of Kashmir?

\section{Research Methodology}

Significant part of the study depends on secondary sources. But information has also been obtained from primary sources which include interviews, comments, observations, opinion.Descriptive and analytical methods have been used for the interpretation of 'Secondary data' going through the possibly available relevant material due to certain constraints in visiting the occupied Kashmirin person. An open-ended questionnaire was developedspecifically for Kashmiri Muslims, Kashmiri Hindus,Pandits, Buddhist, Sikhs and Christiansfor collection of more authentic and reliable data.Open-ended questions allow respondents to include more information, including their feelings and reasons of agreeing or disagreeing, attitudes, various opinions and understanding of the subject matter. This allows researchers to better access the respondents' true feelings on an issue.Then the collected data was analyzed meticulously with encouraging results towards possible and impartial solution of the Kashmir issue.

\section{Hypothesis}

Firstly, Kashmir is the home of religious, political and economic suspicion and frustration on the basis of failure of reconciliation dialogue at national and international levels being unequal power of Pakistan and India and 
secondly, balance of power may guarantee a successful dialogue. Possible apprehension is that both internal and external intentions are not favorable. Prolongation of conflicts and certain issues through power is no solution instead sincere and meaningful dialogue is the solution.

\section{Significance of the Study}

The significance of the present study lies in the undeniable fact that the world has to change the mechanism of international policies specifically where imbalance of power exists as the real and perceived power differences ever created profound barriers to meaningful dialogue on the basis of 'might is right'.The very reason of unjustifiable protraction in solution of the Kashmir issue is self-evident which no doubt is a strategic, political and economic crisis and not only a religious one.Either it is India or China or Pakistan, the focus is on the territory of Kashmir and not people of Kashmir. The people have to change their point of view about such issues worldwide on the basis of ground realities.Power imbalance more or less is always there in the world but human beings must not and cannot be oppressed and suppressed through might for good.

\section{Data Collection and Analysis}

The researcher collected and analyzed the most common points out of the responses of different respondents, in response to each question in the questionnaire, as follows:

Question-1: Is Kashmir a religious or political issue?

Answer-1:Kashmir has multifarious internal and external problems but peace continues to elude the strife-torn Kashmir Valley on the India-Pakistan border, with religious and sectarian violence ever escalating. Recent figures show that 450 people were killed in the Indian part of Kashmir in 2017 in an upward trend in incidents of intermittent bloodshed, curfews and killings."It is a Kashmiri who is getting killed. Whether there is a blast, suicide attack or encounter, the lives of Kashmiris are getting destroyed and devastated.Both nations now administer Kashmir as militants continue their struggle to end Indian rule in India-administered Kashmir, allegedly aided by Pakistan.The Indian-administered area of Kashmir has suffered increased violence since 1989 after militants stepped up armed action to free the region from India. The idea was to create an Islamic state of Jammu and Kashmir; a valley homogenous in its religious character.

Moreover, Kashmir is a complex, egoistic and alarming political issue with a troublesome democratic aberration.The Kashmir problem is and has always been primarily a political problem. And it has to be addressed politically.There are enough people in the country who are worried about it. Eminent people belonging to different political persuasions and their worry must be taken on board.The Centre-appointed interlocutors on Jammu and Kashmir completed the year-long process of interaction with a cross section of people to find a solution to the political issues plaguing the troubled state for long. People need to urge upon the central government to find a solution to the present Kashmir crisis politically rather than administratively.Political uncertainty prevailed in Jammu and Kashmir, because the state administration has gone into a deep slumber leaving the people in distress. The most important issues, referring to AFSPA (Armed Forces Special Power Acts) and Article 370 are under parliamentary consideration. Kashmiri people urged leaders of India and Pakistan to end the "turbulent phase" along the Jammu and Kashmir border, militant insurgencies and military suppression. Political parties in Kashmir always opt for their own political interests and not suffering of the Kashmiri people.

The Hindus of the Kashmir Valley, a large majority of whom were Kashmiri Pandits, were forced to flee the Kashmir valley as a result of being targeted by JKLF and Islamic insurgents during late 1989 and early 1990.Kashmiri Pandits are of the view thatall Kashmiri Muslims are not bad, most of them are innocent and advise young blood in the valley to fight against those people who have been spewing venom, killing innocent people and so called leaders of the people who by the way are Pakistani sympathizers.

Question-2: What do the Kashmiri people want - independence, political rights, or accession to Pakistan or India through self-determination?

Answer-2: The solution is to save Kashmiri people and not to eliminate or destroy them. Political drama in Kashmir - India, Pakistan, Prime Minister and President of Kashmir are just talking, "who will take Kashmir to govern over the helpless people of Kashmir. There is no humanitarian touch both internally and externally. The idea that the dispute over the status of Jammu and Kashmir can be settled only in accordance with the will of the people, which can be ascertained through the democratic method of a free and impartial plebiscite, was the common ground taken by all the three parties to the dispute, viz., the people of Kashmir, Pakistan, and India. 
It was supported without any dissent by the United Nations Security Council and prominently championed by the United States, Britain and other democratic states. It became a matter of controversy only after India realized that she could not win the people's vote.Secondly, what prevented the plebiscite's holding was India's refusal to accept any proposals that called for her to withdraw the bulk of her forces from Kashmir.India's agreement would never be obtained to demilitarization in any form. Kashmiri people appreciate the idea that United States, Britain and France have traditionally been committed supporters of the plebiscite agreement as the only way to resolve this issue.A sincere and serious effort towards a just settlement of the Kashmir dispute must deal with the realities of the situation and fully respond to the people's rights involved in it. A peace process mounted on a fragile platform is bound to collapse. Indeed, any process that ignores the wishes of the people of Kashmir will not only prove to be an exercise in futility but can also cause incalculable human and political damage.

One ground reality about Kashmir is that no leader can claim to be the representative of whole population of Jammu and Kashmir.The Sikhs, Shias, Hindus and Ladakhis are very much critique of separatist movement on the ground that they will be discriminated by majority Sunni community of Kashmir. In Kashmir, no single leader represents the will of people of Jammu and Kashmir. Unless and until there emerged a leadership representing the wishes of all the sections of peoples in Kashmir, it will be difficult to solve Kashmir Issue (Firdos, 2017, p.7)The large military presence in the Kashmir Valley, along with alleged human rights abuses, has stirred disaffection. In 2010, thousands of young Kashmiris took to the streets to protest against Indian rule. They threw stones while the security forces responded with pellet guns and bullets.

About 120 Kashmiris were killed over that summer, which contributed to the radicalizing of a new generation. Last year, protests prompted by the killing of a young and popular armed separatist led to another upsurge of violence.In recent months, some prominent Indian public figures have warned of the scale of the disaffection. Palaniappan Chidambaram, a former home minister, went so far as to say: "The alienation of the people of the Kashmir Valley is almost complete. We are on the brink of losing Kashmir." WajahatHabibullah, once a senior official in Kashmir, lamented that "my life's mission to win over the people of Kashmir for India is lost, irretrievably." He described young Kashmiris as "educated, talented, and consumed with hatred of the Indian state."The Indian government promises attention to Kashmiri concerns, but there's no sign of genuine politicalinitiative ("Kashmirstillsimmering", 2017).

Question-3: What are the economic problems in Kashmir?

Answer-3: In fact, India has impoverished Kashmir. It has taken away most rights from Kashmir to exploit its hydropower resources under the Indus Waters Treaty. Most of the hydroelectric dams operated in J\&K are run by the National Hydropower Corporation (NHPC).About 50 per cent of the electricity produced by NHPC is from projects in $\mathrm{J} \& \mathrm{~K}$, and the state receives little of the benefits. Large part of the grants go into the upkeep of security forces - whose lack of accountability for their crimes is legion.the traders are forced to sell their produce only to a cartel of fruit buyers in Delhi.Instead of azadi (independence), we give Kashmiris AzadpurMandi. The separatist violence has killed more than 47,000 people since 1989, although this toll doesn't include people who have disappeared due to the conflict.India has failed Kashmiris at every step, stolen their resources, their rights, their economic freedom - and then we wonder why they do not love us. Yes, there are people who have become rich because of us - these are the politicians we bribe - as minister of state for external affairs VK Singh so helpfully told.

All this unrest disrupted the region's economy.The Jammu and Kashmir state with its varied and diversified geographic, agro-climatic and topographic features poses very peculiar and unique problems of development and administration. The economy of Jammu and Kashmir has suffered from disturbed conditions prevailing in the State for almost two decades. The potential of Horticulture in $\mathrm{J} \& \mathrm{~K}$ is high, given the rich diversity in its flora and fauna and varied agro-climatic situation.The internal problems in Kashmir economy are more acute now. Decades old conflict and last year floods brought its basic infrastructure on its knees. Institutions were the worst hit in the decades of conflict. Corruption, nepotism and favoritism have plagued our state.Institutional stability, transparency and governance are vital veins of any economic system so is the case for our state.Our state government must take all necessary steps to neutralize the impediments facing the economy.It is imperative that there must be a coherent policy towards the welfare of women. In fact they have taken the brunt of the conflict in Kashmir. 
Our state is showing alarming signs of dependency over the center. Our finances are in mess. Remoteness and isolation from major markets, scattered population, and lack of infrastructure and dislocation of normal civic life during the last two decades - all these factors and characteristics define special developmental challenges.

Question-4: What are religious crises in Kashmir?

Answer-4:"This is not a religious fight. It is a fight for land," says a 20 -year-old businessman. "Though the majority is Muslims, it doesn't mean we want an Islamic state," says a 29-year-old computer professional. The state should be governed by democracy, with sharia law a personal matter, says a 31-year-old businessman (Decoding Kashmir conflict",2011 )Religion-based violence escalates in Kashmir.India, which has controlled most of the Kashmir Valley for the past 70 years, is predominantly Hindu. The valley itself is predominantly Muslim, as is Pakistan.Religion influences many aspects of politics and society and is considered bymany to be an inseparable and integral componentKashmir is conflict territory after the partition of India and Pakistan. Conflict is not only between India and Pakistan but also India and the religious militants. Religious Militants are conducting a jihad to govern by the religious law. Historically, Kashmir included Sufis Muslim not orthodox Muslim. The voices of Pandits advocacy organizations have gained prominence and often serve to create a narrative that forwards the Indian government's interests: painting the conflict in Kashmir as one of Muslim desire for communal hegemony versus the Indian state's secularism and democracy.Numerous international events had influenced the growth of Islamic fundamentalism in Kashmir. Jihad is not originally from Kashmir but they are foreign militancy bought during the end of the Soviet -Afghanistan War.Ethnic conflicts with a strong religious component do not have merely domestic or foreign causes and consequences.

As a result, internationalization of ethnic conflict has become an important subject of inquiry both in terms of pure research and policy-oriented studies (James, 2006, p.447-67).

Although the conflict has long been cast in religious terms yet it's more complicated than that. Kashmir has a long tradition of tolerance despite corruption, non-functioning local government, and meddling from India's capital Delhi in local elections. Adding to the political complexity, the Indian state of Jammu and Kashmir consists of three distinct regions with sharply contrasting cultures and religious profiles: the Kashmir valley, the most populous part of the state and the heartland of Kashmiri culture, has a population of about seven million and is overwhelmingly Muslim; the Jammu region, with a slightly smaller population, has a Hindu majority; and the much more remote area of Ladakh, with a very small population, has cultural ties with Tibet and is itself divided between Buddhist and Shia Muslim areas ("The Asia Dialogue", 2018). The agitation in Kashmir is now more religious in character, than political. The Indian response is equally based on religious lines. The Valley is now seeing a desire for Muslim identify rather than the "Kashmiriyat" of the past.In late 2015 and early 2016, observers of Kashmir reported growth in home-grown Islamic militancy and radicalization of the Kashmiri Muslim population. Several reasons for the growth have been cited such as the absence of a political dialogue, the lack of economic opportunities, frustration due to high unemployment, excessive militarization in the valley and repeated human rights violations by the security forces. The decades-old conflict of Kashmir is based on two factors: claims of nationalism and of religion, having a unique cultural and ethnic identity of their own, and one which demands that it be expressed in a political form - in the shape of an independent Kashmiri state. The dominant Indian nationalist narrative has no space for a separate Kashmiri nation as a political entity. It demands that the Kashmiris must, even through force, recognize themselves as Indians and their land as an integral and indivisible part of India.Competing understandings of religion and religious-based identity are the other principal basis for the desire of many Kashmiri Muslims to be independent of India. This, in turn, is inextricably linked to the notion of the religious 'other' in dominant understandings of Islam ("Kashmir Conflict", 2010).

Question-5: What are the intentions of Pakistan and India on Kashmir issue?

Answer-5: India, Pakistan must show intention to resolve Kashmir issue.Separatist JKLF chairman Mohammad Yasin Malik is of the view that "When there is no intention to resolve Kashmir issue, what are dialogue and negotiations meant for?" It means that dialogue between India and Pakistan will not resolve the Kashmir issue unless the two countries have an intention to do so. There was a lot of hue and cry for dialogue and negotiations. "It is our faith and belief that only peaceful negotiations and dialogue can resolve issues and disputes but for achieving this goal the parties involved in the process have to first show sincerity". Any nation that believes in dialogue process and wants to resolve issues, it first tries to convince its own people about it. "But in this case, the Indian government from Prime Minister down to ministers, whetherit is talking with Pakistan or Kashmiris, is engaged in hardline rhetoric. 
The Indian leaders were publicly pledging not to give any concessions on Jammu Kashmir. Every pro-Indian party and politicians of Jammu and Kashmir have proved a stooge whose foremost job is to safeguard the interests of India.Now it is crystal clear that both India and Pakistan are more interested in defeating each other and not solution of the Kashmir issue.Kashmiris have been sandwiched in between this tit-for-tat approach.Both sides must own their own injustices and rectify them, not only in the name of honest representation of Kashmiris, but also if they want to avoid further instability, violence and unrest."'The Office of the United Nations' High Commissioner for Human Rights released a first of its kind report documenting alleged human rights violations in Kashmir on $14^{\text {th }}$ June, 2018.India dismissed it as "fallacious, tendentious and motivated" and Indian officials claimed that there cannot be any comparison between Indian-held Kashmir and Pakistani Kashmir as "the former has a democratically elected government" ("U.N Human Rights Report on Kashmir", 2018 ).

Two things that brought India together in anger then: Pressure from Western human rights organizations and that disastrous statement from US Assistant Secretary of State Robin Raphel questioning the validity of the instrument of Kashmir's accession to India.Now this irresponsible UN report has brought in both these provocations. Having vented at the stupidity of the UN repeating its own and the Western powers' blunders, as personified by Robin Raphel in 1993, we should also reflect on how we got here. Simple answer: By making blunders very similar to that past.India's rejection of the report must then be seen as not only a rejection of the UN inquiry, but a dismissal of all the investigations and documentation of human rights abuses by Indian and international watchdogs.

Meanwhile, Pakistan has welcomed the proposal to set up a Commission of Inquiry to investigate human rights violations in Indian-held Kashmir, stating that the report is in line with the concerns raised by Pakistan over the years.

"Let's be realistic: India's never going to give up this land," said one young Kashmiri who asked that his identity not be revealed because he could be labeled a collaborator."I can say such things in my house. But as soon as I step outside, even into my own street, I can't say that. It has to be 'Azadi! Azadi! Azadi!' " he said, using the word for freedom. "It's like you have to be two different people, all the time ("Kashmir War", 2018). India's identity was the fear, though over time these anxieties have been dissipatedthrough continuous hard struggle and actions of Indian leadership that the loss ofKashmir would set a precedent for other regions in Indian Union to break apart(Basrur, 2008).Pakistan considers it as an unfinished agenda of the division of India in 1947. Pakistan regards it as an issue of giving the right of self-determination to the Kashmiris, a principle also accepted by the UN Security Council Resolution. The Pakistani concerns on the water issue that increases the significance of Kashmir issue for Pakistan is still present.The Kashmir conflict had its origin in the unfulfilled promises made by India. There is no denying the fact that economic and military imbalance between Pakistan and India is the real reason behind India's refusal to settle the dispute with Pakistan. The same reason forced Pakistan to acquire the nuclear capability to neutralize Indian conventional might (Javed, 2015, p.45-69).India not only intends to keep its hold over Kashmir but would move forward to destabilize Pakistan to dictate policies to it. On the other hand Pakistan policy makers strongly believe if India is sincere in improving relations with Pakistan, it must first resolve the Kashmir issue. India leadership realizing their failure to win the support of Kashmiri people finds it difficult to start a meaningful dialogue with Pakistan on the issue.India's denial of economic, political and democratic rights to Kashmiri people, forced them to rise against India (Mahmood, 2001, p.7-24). Despite the oppression and deprivation, Kashmiris are fighting for their identity.

Question-6: What are the possible solutions to the long outstanding issue of Kashmir?

Answer-6: Possible solutions to a long outstanding issue of Kashmir are as follows:

(i) Kashmir has been a flashpoint between India and Pakistan for more than 60 years. Currently a boundary - the Line of Control - divides the region in two, with one part administered by India and one by Pakistan. India would like to formalize this status quo and make it the accepted international boundary. But Pakistan and Kashmiri activists reject this plan because they both want greater control over the region.

(ii) Pakistanhas consistently favored that Kashmiris should join Pakistan, this is the best solution to the dispute. In view of the state's majority Muslim population, it believes that it would vote to become part of Pakistan. However a single plebiscite held in a region which comprises peoples that are culturally, religiously and ethnically diverse, would create disaffected minorities. The Hindus of Jammu, and the Buddhists of Ladakh have never shown any desire to join Pakistan and would protest at the outcome. 
(iii) In case Kashmir joins India, this solution would be unlikely to bring stability to the region as the Muslim inhabitants of Pakistani-administered Jammu and Kashmir, including the Northern Areas, have never shown any desire to become part of India.

(iv) Independent Kashmir, the difficulty of adopting this as a potential solution is that it requires India and Pakistan to give up territory, which they are not willing to do. Any plebiscite or referendum likely to result in a majority vote for independence would therefore probably be opposed by both India and Pakistan. It would also be rejected by the inhabitants of the state who are content with their status as part of the countries to which they already owe allegiance.

(v) A smaller independent Kashmir could be created from the Kashmir Valley - currently under Indian administration - and the narrow strip of land which Pakistan calls Azad Jammu and Kashmir. This would leave the strategically important regions of the Northern Areas and Ladakh, bordering China, under the control of Pakistan and India respectively. However both India and Pakistan would be unlikely to enter into discussions which would have this scenario as a possible outcome.

(vi) 'An independent Kashmir Valley' has been considered by some as the best solution because it would address the grievances of those who have been fighting against the Indian Government since the insurgency began in 1989. But critics say that, without external assistance, the region would not be economically viable.

(vii) The Chenab formula - this plan, first suggested in the 1960s, would see Kashmir divided along the line of the River Chenab. This would give the vast majority of land to Pakistan and, as such, a clear victory in its longstanding dispute with India.

The entire valleywith its Muslim majority population would be brought within Pakistan's borders, as well as the majority Muslim areas of Jammu ("Possible Solution of Kashmir", 2010).

\section{Conclusion}

The researcher is of the view that in the present era, the 'reconciliation trends' are constantly changing on the bases of economic, political and strategic grounds. Today in the hierarchy of priorities for a state, 'religion and ethnicity' may be found at the bottom. Firstly, the very case of Kashmir is a living example wherein India, Pakistan, China and politics in Kashmir - all are endeavoring especially for the strategic position of Kashmir. Secondly, people support and vote for a country that has got sound economy and political position in the world. Thirdly, India does not want to give the option of 'Self-rule' or 'self-determination' to Kashmir state otherwise other thirty states may also demand the right of 'self-determination'. Fourthly, in Kashmir, there is no 'humanitarian' touch both internally and externally.Kashmir has become an issue of 'territory occupation' and not the issue of heart-rending plight of the Kashmiri people. For worldly gains, so-called politicians and sometimes so-called religious leaders cross all limits. Fifthly, the Kashmir dialogue ever failed - (i) imbalance of power between India and Pakistan, (ii) UNO permanent members do not want the solution because of their own interests and exploitation of India and Pakistan, (iii) the style of dialogue is 'callous and violent' and (iv) the process of dialogue is dictated by egoism and egotism. In a word, the consistent solution of Kashmir issue lies with Pakistan, India, China and the people of Kashmir through the policy of 'give and take'.

\section{Recommendations}

In the light of hypothesis, research questions, collected and analyzed data and conclusion of the study, the research would recommend: (i) Pakistan, India, China and the people of Kashmir should focus specifically on the plight and suffering of Kashmiris and not only its beautiful territory, (ii) the process of dialogue must not be stopped, (iii) the style of dialogue needs to be 'non-violent, peaceful,and impartial', (iv)people at all levels have to say 'No' to terrorism whatever, e.g. - individual-level, group-level and state-level, (v) love people of Kashmir both internally and externally at international level, (vi) attend different dimensions of problems in Kashmir - the humanitarian dimension, internal and external dimensions, dimension of special positions of Jammu and Kashmir, dimension of regional imbalances and regional problems, (vii) the people concerned need to address all problems and especially the most complex problem of politics, in an integrated manner and (viii) people at all levels need to put head and heart together to take 'decisions' and 'not only recommendations' to do something in future because that future would never come. 'Retrospection' of ever deteriorating situation in Kashmir through the past seventy years would make the point crystal clear. 


\section{References}

Ali, Tariq et al. (2011) Kashmir the Case for Freedom. London, UK: Verso

Choudhry, G.W. (1968). Pakistan's Relations with India, 1947-1966. London. Pall Mall Press.

Dialogue in Islam. Retrieved from https://www.google.com=dialogue +in+islam

Das, N.K. (2006). People of India and Indian Anthropology.Economic and PoliticalWeekly.3156-59.

Decoding Kashmir conflict. Retrieved from https://www.csmonitor.com/Decoding-Kashmir+conflict/

Firdos, A.B. (2017). Constraints in Solving Kashmir Problem, India: Journal of Political Sciences \& Public Affairs. Pol Sci Pub Aff 5: 248. doi:10.4172/2332-0761.100024805

Ganguly, S. (2007).The Roots of Religious Violence in India, Pakistan and Bangladesh.London. Routlege.

Hussain, M.F. (2003).Islam the Religion of Dialogue.(Translated by Najim al-Khafaji) Beirut, Lebanon: DarAlmalak.

Interfaith Dialogue. Retrieved from https://www.google.com=interfaith+dialogueIndia Makes Kashmir Poorer. Retrieved from https://www.dailyo.in/politics/india-makes-kashmir-poorer-not-richer.html

Javed, M. C. (2015). Pakistan-India Conflict with Special Reference to Kashmir.A Research Journal of South Asian Studies. Vol. 30, No.1, January - June 2015, pp. 45 - 69.

James, Carolyn. C. (2006). Religion as a Factor in Ethnic Conflict: Kashmir and Indian Foreign Policy Carolyn C. James \& Özgür Özdamar Pages 447-467

Kashmir War. Retrieved from https://www.nytimes.com/2018/08/01/world/asia/kashmir-war-india-pakistan.html

Korbel, J. (1954). Danger in Kashmir.New Jersey, USA: Princeton University Press.

Kung, Hans. Retrieved from https://www.goodreads.com/quotes/157789-no-peace-among-the-nations-withoutpeace-among-the-religions

Kurucan, A. \& Mustafa, K.E. (2012).Dialogue in Islam: Qur'an - Sunnah - History. Great Britain: Dialogue Society.

Kashmir Conflict. Retrieved from (https://en.qantara.de/content/the-kashmir-conflict-a-clash-of-nationalisms-andreligions

Kashmir still simmering. Retrieved from https://qz.com/india/1112379/70-years-after-the-crisis-broke-out-why-iskashmir-still-simmering/

Lamb, Alastair (2002). Kashmir: A Disputed Legacy: 1846 - 1990. Karachi: OxfordUniversity Press.

Malik, I. (2002). Kashmir Ethnic Conflict International Dispute. Karachi: OxfordUniversity Press.

Schofield, V. (2003).Kashmir in Conflict: India, Pakistan and the Unending War. London \& New York: I.B. Tauris.

Soz, Saifuddin. (2018). Kashmir: Glimpses of History and the Story of Struggle. New Delhi, India: Rupa Publications.

The Message International. Retrieved from http://messageinternational.org/the-quranic-perspective-on-interfaithdialogue/

Tavares, R. (2008). Resolving the Kashmir Conflict: Pakistan, India, Kashmiris and

Religious Militants.The Asia Dialogue.Asian Journal of Political Science. Retrieved from http://theasiadialogue.com/2018/07/02/kashmir-faces-new-crisis/

U.N. Human Rights Report on Kashmir. Retrieved from https://theprint.in/The Print (News Paper) in India 